\title{
Comprehensive analysis of $\beta$-catenin target genes in colorectal carcinoma cell lines with deregulated Wnt/ $\beta$-catenin signaling
}

\author{
Andreas Herbst ${ }^{*}$, Vindi Jurinovic ${ }^{2}$, Stefan Krebs ${ }^{3}$, Susanne E Thieme ${ }^{3}$, Helmut Blum³ ${ }^{3}$ Burkhard Göke \\ and Frank T Kolligs ${ }^{1}$
}

\begin{abstract}
Background: Deregulation of Wnt/ $\beta$-catenin signaling is a hallmark of the majority of sporadic forms of colorectal cancer and results in increased stability of the protein $\beta$-catenin. $\beta$-catenin is then shuttled into the nucleus where it activates the transcription of its target genes, including the proto-oncogenes MYC and CCND1 as well as the genes encoding the basic helix-loop-helix (bHLH) proteins ASCL2 and ITF-2B. To identify genes commonly regulated by $\beta$-catenin in colorectal cancer cell lines, we analyzed $\beta$-catenin target gene expression in two non-isogenic cell lines, DLD1 and SW480, using DNA microarrays and compared these genes to $\beta$-catenin target genes published in the PubMed database and DNA microarray data presented in the Gene Expression Omnibus (GEO) database.

Results: Treatment of DLD1 and SW480 cells with $\beta$-catenin siRNA resulted in differential expression of 1501 and 2389 genes, respectively. 335 of these genes were regulated in the same direction in both cell lines. Comparison of these data with published $\beta$-catenin target genes for the colon carcinoma cell line LS174T revealed 193 genes that are regulated similarly in all three cell lines. The overlapping gene set includes confirmed $\beta$-catenin target genes like AXIN2, MYC, and ASCL2. We also identified 11 Kyoto Encyclopedia of Genes and Genomes (KEGG) pathways that are regulated similarly in DLD1 and SW480 cells and one pathway - the steroid biosynthesis pathway - was regulated in all three cell lines.

Conclusions: Based on the large number of potential $\beta$-catenin target genes found to be similarly regulated in DLD1, SW480 and LS174T cells as well as the large overlap with confirmed $\beta$-catenin target genes, we conclude that DLD1 and SW480 colon carcinoma cell lines are suitable model systems to study Wnt/ $\beta$-catenin signaling and associated colorectal carcinogenesis. Furthermore, the confirmed and the newly identified potential $\beta$-catenin target genes are useful starting points for further studies.
\end{abstract}

Keywords: Colorectal cancer, $\beta$-catenin, Target genes, DLD1, SW480, LS174T, DNA microarray

\section{Background}

The majority of sporadic forms of colorectal cancer are characterized by deregulation of $\mathrm{Wnt} / \beta$-catenin signaling resulting in increased transcriptional activity of the protein $\beta$-catenin. In colon cells, a protein complex consisting of the protein Adenomatous polyposis coli (APC), the scaffolding protein Axin, casein kinase 1 (CK-1) and glycogen synthase kinase $3 \beta$ (GSK-3 $\beta)$ tightly controls the transcriptional

\footnotetext{
* Correspondence: Andreas.Herbst@med.uni-muenchen.de

'Department of Medicine II, University of Munich, Marchioninistrasse 15, 81377 Munich, Germany

Full list of author information is available at the end of the article
}

activity of the $\beta$-catenin protein by targeting it for proteasomal degradation. Stimulation of colon cells with Wnt proteins results in the disruption of the APC protein complex and stabilization of the $\beta$-catenin protein. $\beta$-catenin is then transported into the nucleus where it recruits cofactors of the TCF/LEF family to activate the transcription of its target genes [1]. In colorectal tumor cells, the tumor suppressor gene APC is frequently affected by loss of heterozygosity $(\mathrm{LOH})$ as well as mutations, resulting in inactivation of the APC protein complex targeting $\beta$-catenin for degradation $[2,3]$. Consequently, $\beta$-catenin activity is deregulated and promotes aberrant transcription of its target genes [1].

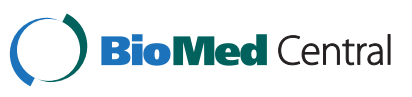


$\beta$-catenin target genes have been implicated in regulating different cellular processes including proliferation (e.g., MYC, CCND1, PPARD), stem cell fate (ASCL2), survival (ABCB1, BIRC5), differentiation (ID2, ITF2, ENC1), migration (MMP7, MMP14), and angiogenesis (VEGF) [4-18]. While these $\beta$-catenin functions play an important role in embryonic development and tissue homeostasis, they can also contribute to the initiation and progression of colon cancer. In particular, deregulation of genes involved in proliferation and migration is frequently observed in colorectal carcinomas [5-7,14-16].

Genes encoding members of the basic helix-loop-helix (bHLH) family of proteins, like ASCL2, HATH1, and ITF2, represent one of the largest groups of genes on the list of previously published $\beta$-catenin target genes $[8,19,20]$. Members of the bHLH protein family are characterized by the presence of a basic DNA binding domain and a HLH protein-protein interaction domain. Based on their primary sequence, bHLH proteins are grouped into seven classes and are known to form homo- and heterodimers to regulate their functions [21]. For example, the class I bHLH protein ITF-2B encoded by the gene ITF2 is known to interact with class II and class V bHLH proteins [22].

The colon carcinoma cell lines, DLD1 and SW480, are frequently used as model systems to study colorectal carcinogenesis in general and $\beta$-catenin function in particular. To identify target genes that are commonly regulated by $\beta$-catenin, we chose these non-isogenic colorectal cancer cell lines for our experiments. While DLD1 cells are derived from a microsatellite instable (MSI) tumor, SW480 tumor cells are characterized by chromosomal instability (CIN) [23]. In both cell lines the APC gene is affected by $\mathrm{LOH}$ on chromosome 5 and contains inactivating mutations in the remaining APC allele [24]. In contrast, the MSI colon carcinoma cell line LS174T -that was used for validation purposes- expresses wild-type APC and a mutated $\beta$-catenin protein $[23,24]$.

Here, we analyzed the gene expression profiles of DLD1 and SW480 cells after down regulation of $\beta$-catenin expression and compared the potential $\beta$-catenin target genes that are similarly regulated in DLD1 and SW480 cells with a comparable data set published for LS174T cells in the Gene Expression Omnibus (GEO) database as well as confirmed $\beta$-catenin target genes found in the PubMed database. We also identified 11 Kyoto Encyclopedia of Genes and Genomes (KEGG) pathways that are regulated similarly in DLD1 and SW480 cells. In addition, one KEGG pathway was regulated in all three cell lines. Based on the large number of genes that are regulated in a similar way in DLD1, SW480, and LS174T cells as well as the large overlap with previously published $\beta$-catenin target genes, we conclude that DLD1 and SW480 are good model systems to study $\beta$-catenin target genes and signaling pathways. Furthermore, we were able to confirm a large number of previously published $\beta$-catenin target genes and identified many new potential $\beta$-catenin target genes. Therefore, this data is a useful resource for further studies to elucidate the role of $\beta$-catenin signaling in colorectal cancer.

\section{Results}

\section{Identification of $\beta$-catenin target genes in DLD1 and}

\section{SW480 colon carcinoma cells}

To test the efficacy of the $\beta$-catenin siRNA used for our DNA microarray experiments, DLD1 and SW480 cells were treated with this $\beta$-catenin siRNA and $\beta$-catenin protein expression was analyzed using immuno detection. Since we observed the strongest down regulation of $\beta$ catenin protein after siRNA treatment for $48 \mathrm{hrs}$, cells were treated for this period of time. Compared to DLD1 and SW480 cells treated with control siRNA (sißgal), treatment with $\beta$-catenin siRNA (si $\beta$ cat) attenuated $\beta$-catenin protein expression levels in both cell lines (Figure 1A). Similarly, treatment of DLD1 and SW480 cells with $\beta$-catenin siRNA strongly reduced the activity of the $\beta$-catenin dependent

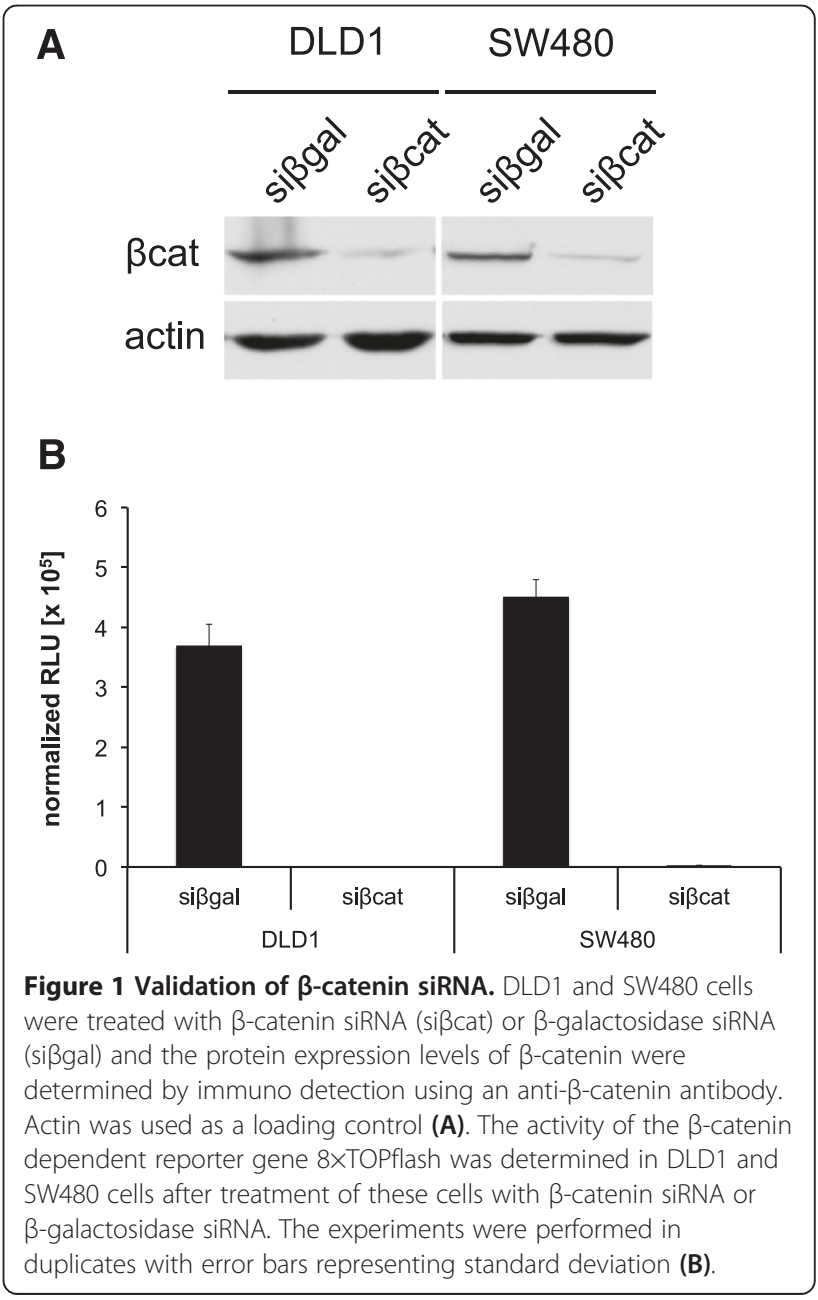


$8 \times$ TOPflash reporter gene construct, confirming the efficacy of the $\beta$-catenin siRNA (Figure 1B).

To identify commonly regulated $\beta$-catenin target genes in colorectal cancer cell lines, we analyzed the expression of $\beta$-catenin target genes in DLD1 and SW480 cells after siRNA treatment of these cells using DNA microarrays. Treatment of DLD1 and SW480 cells with siRNA targeting $\beta$-catenin resulted in differential expression of 1501 and 2389 genes, respectively (Figure 2A and Additional file 1, tab "DLD1 complete" and "SW480_complete"). The intersecting set comprised 335 genes, which are regulated in the same direction in both cell lines (Figure 2A and Additional file 1, tab "335 target genes"). We compared the lists of potential $\beta$-catenin target genes obtained for DLD1 and SW480 cells to a previously published data set containing differentially expressed genes after treatment of the colon carcinoma cell line LS174T with $\beta$-catenin shRNA. Out of the 5543 differentially expressed genes in LS174T cells (Additional file 1, tab "LS174T_complete"), 786 genes and 677 genes were regulated similarly in DLD1 and SW480 cells, respectively. Furthermore, we identified 193 genes that are regulated in the same direction in all three cell lines (Figure 2A and Additional file 1, tab "DLD1_SW480_LS174T_only").

Out of the 193 genes that are up or down regulated in DLD1, SW480, and LS174T cells, 4 genes (ASCL2, AXIN2, MYC, and S100A6) have previously been described as $\beta$ catenin target genes (compare Table 1 and Additional file 1, tab "DLD1_SW480_LS174T_only"; This tab also contains the false discovery rate (FDR) as well as the fold change (FC) for each gene). In addition, we identified the genes ABCB1, CD44, FGF18, and HEF1 (NEDD9) as potential $\beta$ catenin target genes in DLD1 and SW480 cells (Additional file 1, tab "335 target genes"; This tab also contains the false discovery rate (FDR) as well as the fold change (FC) for each gene).

Based on a literature search in the PubMed database, we identified 33 genes that are regulated in a $\beta$-catenin dependent manner in addition to the $33 \beta$-catenin target genes published by Roel Nusse. (All these genes are differentially regulated either in normal colon, colon carcinoma cells, or colon carcinoma cell lines.) 38 out of these 66 genes are directly regulated by $\beta$-catenin as demonstrated by ChIP, EMSA, or RGA with mutated (canonical) TCF4 binding sites (Table 1). When we reanalyzed the microarray data focusing our analysis only on the list of these 66 previously published $\beta$-catenin target genes, we identified 21 (DLD1), 30 (SW480), and 34 (LS174T) of these genes as differentially regulated in the three cell lines, respectively (Figure $2 \mathrm{~B}$ and Additional file 2). The genes ASCL2, AXIN2, MYC, NOTCH2, S100A6, and SP5 were regulated in DLD1, SW480, and LS174T cells. Moreover, we found that the genes ABCB1, CD44, FGF18, HEF1 (NEDD9), and ITF2 (TCF4) were also differentially regulated in DLD1 and SW480 cells (see Additional file 2, "DLD1_SW480_LS174T_only" and tab "DLD1_SW480_complete"). Thus, our second analysis using a limited number of genes confirmed our first microarray analysis using all differentially expressed genes and identified the genes ITF2 (TCF4), NOTCH2 and SP5 as $\beta$-catenin target genes in addition to ABCB1, ASCL2, AXIN2, CD44, FGF18, MYC, HEF1 (NEDD9), and S100A6 found in the first analysis.

Due to the large number of genes encoding members of the basic helix-loop-helix (bHLH) family of proteins among the list of $\beta$-catenin target genes ( 6 out 66 genes; Table 1), we were interested in identifying more members of this family of genes in our microarray data set.

When we re-analyzed the microarray data limiting our analysis to the $96 \mathrm{bHLH}$ proteins listed in the PFAM database, we identified the genes ASCL2 and MYC as differentially regulated in DLD1, SW480, and LS174T cells (see Additional file 3, tab "DLD1_SW480_LS174T_only"). In DLD1 and SW480 cells, the genes ID1, and ITF2 (TCF4) were also differentially regulated (Figure $2 \mathrm{C}$ and Additional file 3, tab "DLD1_SW480_complete"). Taken together, out of the six $\beta$-catenin target genes belonging to the bHLH family of proteins (Table 1), three genes (ASCL2, ITF2 (TCF4), MYC) are commonly regulated in DLD1 and SW480 cells.

Using the software package "Cytoscape" in combination with the "Michigan Molecular Interactions" (MiMI) plugin, we searched the list of 193 genes that are differentially regulated in DLD1, SW480, and LS174T cells for known interactions. We identified three networks that contained three or more nodes (genes) (Figure 3A). The largest network centered on $\beta$-catenin comprised 18 genes, while the second largest network with 6 genes contained the gene YWHAZ encoding the $14-3-3$ protein isoforms $\xi / \delta$ at its center. The smallest network contained the three nodes NET1, ARHGAP29, and DEPDC7 (Figure 3A). When we focused our analysis on the list of 335 genes that are differentially regulated in DLD1 and SW480 cells, we identified the same three networks that we found in the intersection of DLD1, SW480, and LS174T cells. However, the network centered on $\beta$-catenin was increased to 36 genes, while the network containing the gene YWHAZ comprised two additional nodes ( 8 in total). The smallest network contained the four nodes NET1, ARHGAP29, ABR and DEPDC7 (Figure 3B). Interestingly, both panels highlight the $\beta$-catenin target gene MYC as a major player with 10 and 19 directly regulated genes, respectively (Figure 3A and $\mathrm{B})$.

Apart from identifying potential $\beta$-catenin target genes, we were interested to find out if particular signaling pathways or cellular functions are regulated by $\beta$-catenin. We used the gene set enrichment software (GSEA) software $[80,81]$ to identify pathways associated with $\beta$-catenin 


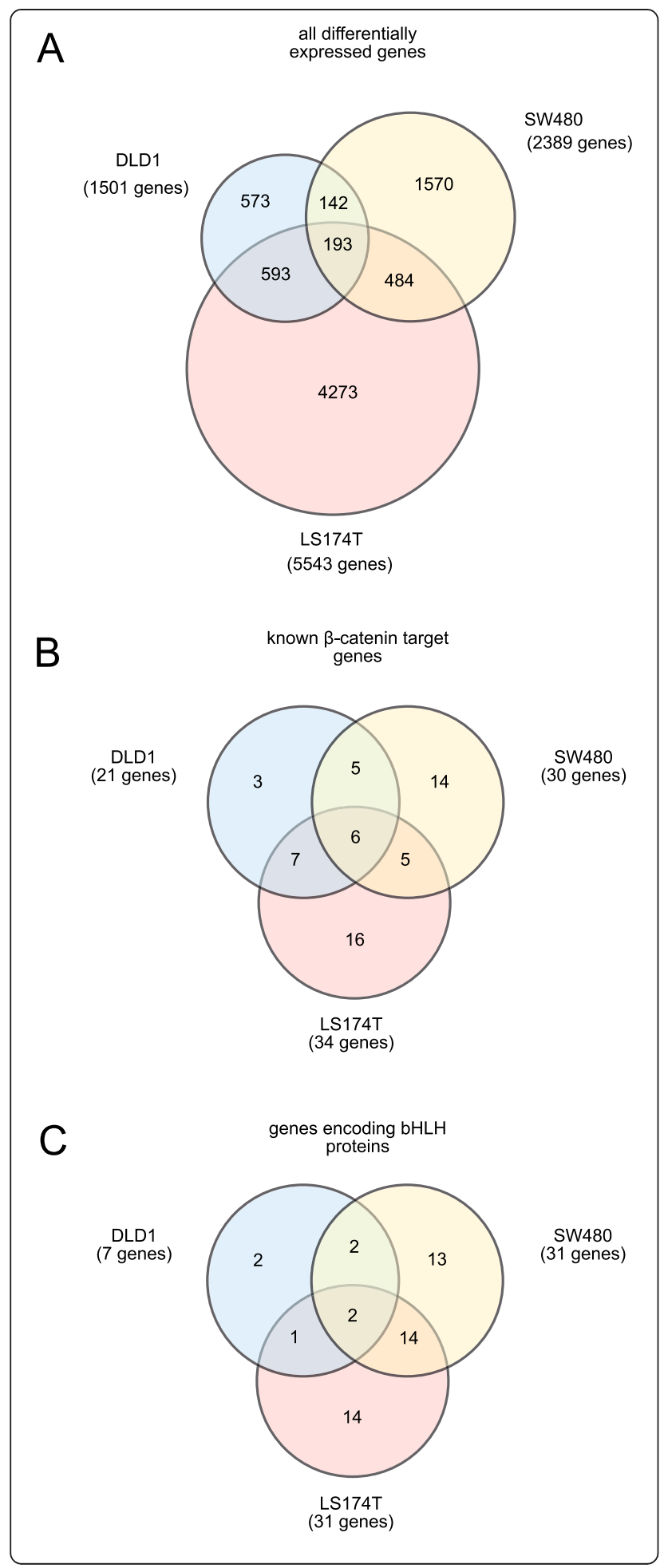

Figure 2 Identification of $\beta$-catenin target genes. DLD1 and SW480 cells were treated with $\beta$-catenin siRNA and differentially expressed genes were identified using a DNA microarray. The corresponding data for LS174T cells was published earlier and used for comparison. The Venn-like diagrams display the number of differentially expressed genes when analyzing all differentially expressed genes (A), previously described $\beta$-catenin target genes listed in Table 1 (B), or 96 genes encoding basic helix-loop-helix (bHLH) proteins (PFAM family PF00010) (C). The names of the genes corresponding to the seven sections of each Venn-like diagram are listed in separate tabs in the Additional files 1,2 and 3.

siRNA treatment. In DLD1 and SW480 cells treated with control siRNA 2 KEGG pathways were enriched. These pathways comprised the glycine, serine and threonine metabolism as well as the renin angiotensin system. After down regulation of $\beta$-catenin expression levels, the following 9 KEGG pathways were enriched in DLD1 and SW480 cells: endocytosis, insulin signaling pathway, lysosome fc gamma $\mathrm{r}$ mediated phagocytosis, apoptosis, regulation of actin cytoskeleton, adipocytokine signaling, glycerolipid metabolism, lysosome and aldosterone regulated sodium reabsorption (Table 2). In addition, the steroid hormone biosynthesis pathway was enriched in DLD1, SW480, and LS174T cells after treatment with $\beta$-catenin siRNA (Table 2). Apart from the KEGG pathway database, we also used the Biocarta pathway database in the gene set enrichment analysis. Down regulation of $\beta$-catenin resulted in the enrichment of the M-calpain pathway, the Creb pathway, and the IGF1R pathway in DLD1 and SW480 cells (Additional files 4 and 5).

\section{Discussion}

$\beta$-catenin plays a crucial role in embryogenesis, tissue homeostasis and carcinogenesis. Because of its role in regulating homeostasis of the intestinal tract as well as being a key player in sporadic forms of colorectal cancer, inhibition of $\beta$-catenin is not a suitable strategy to treat patients with colorectal cancer. For this reason, identifying and characterizing $\beta$-catenin target genes could result in better understanding of colorectal carcinogenesis and development of new therapies. Here, we used two nonisogenic colorectal cancer cell lines, DLD1, and SW480, and identified 335 commonly regulated $\beta$-catenin target genes. 193 of these genes were also differentially regulated in LS174T cells. (Genes that are differentially expressed due to the genetic background of a given cell should be deregulated to a similar extent irrespective of the siRNA treatment and hence should not appear as being differentially regulated in the DNA microarray experiment.) Compared to the number of differentially regulated genes in LS174T and DLD1 cells (786 genes) as well as in LS174T and SW480 cells (677 genes), the number of commonly regulated genes in DLD1 and SW480 (335 genes) was low, resulting in a low number of commonly regulated genes in 
Table $1 \beta$-catenin target genes in human colon or colon carcinoma cells (including colon carcinoma cell lines)

\begin{tabular}{|c|c|c|c|c|c|}
\hline Gene & Protein & $\begin{array}{l}\text { Direct } \\
\text { regulation }\end{array}$ & $\begin{array}{l}\text { Method to study } \\
\text { direct regulation }\end{array}$ & $\begin{array}{l}\text { Induction/ } \\
\text { Reduction }\end{array}$ & Reference \\
\hline ABCB1 & $A B C$ multidrug transporter & Yes & $\begin{array}{l}\text { EMSA, RGA w/ mutated } \\
\text { reporter gene }\end{array}$ & Up & [9] \\
\hline ADAM10 & $\begin{array}{l}\text { Disintegrin and metalloproteinase } \\
\text { domain-containing protein 1a }\end{array}$ & Not analyzed & RGA & Up & [25] \\
\hline ALEX1 & $\begin{array}{l}\text { Armadillo repeat-containing } \\
\text { X-linked protein } 1\end{array}$ & Not analyzed & $\begin{array}{l}\text { RGA, ChIP for CREB; activation } \\
\text { mediated by CREB (CRE) und E } \\
\text { boxes within the ALEX1 promoter }\end{array}$ & Up & {$[26]$} \\
\hline ASCL2 & Achaete-scute homolog 2 & Not analyzed & qRT-PCR & Up & [8] \\
\hline AXIN2* & Axin-2 & Not analyzed & RGA & Up & {$[27-29]$} \\
\hline BAMBI & $\begin{array}{l}\text { BMP and activin } \\
\text { membrane-bound inhibitor }\end{array}$ & Yes & RGA w/ mutated reporter gene & & {$[30]$} \\
\hline BCL2L2 & $\mathrm{BCl}$-2-like protein 2; BCLW & Yes & ChIP & Up & [31] \\
\hline BIRC5* & $\begin{array}{l}\text { Survivin, Baculoviral IAP } \\
\text { repeat-containing protein } 5\end{array}$ & Yes & EMSA, RGA w/ mutated reporter gene & Up & {$[10]$} \\
\hline BMI1 & Polycomb complex protein BMI-1 & Not analyzed & RGA & Up & {$[32]$} \\
\hline BMP4* & Bone morphogenetic protein 4 & Not analyzed & Northern blot & Up & [33] \\
\hline CCND1* & Cyclin-D1 & Yes & EMSA & Up & {$[5,6]$} \\
\hline CD44* & CD44 antigen & Not analyzed & - & Up & {$[34,35]$} \\
\hline CDKN2A & p16INK4a & Yes & ChIP & Up & {$[36]$} \\
\hline CDX1 & Homeobox protein $\mathrm{Cdx}-1$ & Yes & RGA w/ mutated reporter gene & Up & {$[37]$} \\
\hline CLDN1* & Claudin-1 & Yes & RGA & Up & {$[38]$} \\
\hline $\operatorname{cox} 2$ & cyclooxygenase-2 & Yes & EMSA, RGA w/ mutated reporter gene & Up & {$[39]$} \\
\hline DKK1* & Dickkopf-1 & Yes & EMSA & Up & {$[40]$} \\
\hline DKK4* & Dickkopf-4 & Not analyzed & RGA, siRNA/qRT-PCR & Up & {$[41,42]$} \\
\hline DNMT1 & DNA methyltransferase 1 & Not analyzed & RGA & Up & {$[43]$} \\
\hline EDN1* & endothelin-1 & Yes & ChIP & Up & [44] \\
\hline EFNB $1 *$ & Ephrin-B1 & Not analyzed & Northern blot & Down & {$[45]$} \\
\hline ENC1 & ectodermal-neural cortex 1 & Yes & RGA w/ mutated reporter gene & Up & [13] \\
\hline EPHB2 & Ephrin type-B receptors & Not analyzed & Northern blot & Up & {$[45]$} \\
\hline EPHB3 & Ephrin type-B receptors & Not analyzed & Northern blot & Up & {$[45]$} \\
\hline FGF18* & Fibroblast growth factor 18 & Yes & EMSA & Up & {$[45,46]$} \\
\hline FGFBP & $\begin{array}{l}\text { Fibroblast growth } \\
\text { factor-binding protein }\end{array}$ & Yes & RGA w/ mutated reporter gene & Up & [47] \\
\hline FRA $1 *$ & Fos-related antigen 1 & Yes & EMSA & Up & [48] \\
\hline FSCN1 & Fascin1 & Yes & ChIP & Up & [49] \\
\hline GAST* & Gastrin & Not analyzed & RGA & Up & {$[50]$} \\
\hline HATH $1 *$ & human ortholog of atonal 1 & Not analyzed & RGA & Down & [19] \\
\hline $\begin{array}{l}\text { HEF1 } \\
\text { (NEDD9) }\end{array}$ & human enhancer of filamentation 1 & Yes & ChIP & Up & [51] \\
\hline HES1 & Hes1 (Hairy and enhancer of split 1) & Yes & RGA w/ mutated reporter gene & Up & {$[52]$} \\
\hline ID2* & DNA-binding protein inhibitor ID-2 & Yes & EMSA & Up & {$[11,12]$} \\
\hline ITF2 (TCF4)* & Immunoglobulin transcription factor 2 & Not analyzed & RGA & Up & {$[20]$} \\
\hline JAG1* & Jagged-1 & Yes & ChIP & Up & [53] \\
\hline JUN* & Transcription factor AP-1 & Yes & EMSA & Up & [48] \\
\hline L1CAM* & L1 neuronal cell adhesion molecule & Yes & EMSA & Up & [54] \\
\hline LAMC2 & Laminin subunit gamma-2 & Yes & EMSA, RGA w/ mutated reporter gene & Up & {$[55]$} \\
\hline
\end{tabular}


Table $1 \beta$-catenin target genes in human colon or colon carcinoma cells (including colon carcinoma cell lines) (Continued)

\begin{tabular}{|c|c|c|c|c|c|}
\hline LEF1* & Lymphoid enhancer-binding factor 1 & Yes & DNAse footprint, ChIP & Up & {$[56-58]$} \\
\hline LGR5* & $\begin{array}{l}\text { Leucine-rich repeat-containing } \\
\text { G-protein coupled receptor } 5\end{array}$ & Not analyzed & - & Up & [59] \\
\hline MENA & ENAH, Mammalian enabled homologue & Yes & ChIP & Up & [60] \\
\hline MET* & Hepatocyte growth factor receptor & Not analyzed & - & Up & [61] \\
\hline MMP14 & $\begin{array}{l}\text { Matrix metalloproteinase-14 } \\
\text { (old name: MT1-MMP) }\end{array}$ & Yes & EMSA, RGA w/ mutated reporter gene & Up & [16] \\
\hline MMP7* $^{*}$ & Matrilysin & Not analyzed & RGA & Up & {$[14,15]$} \\
\hline MYB & Transcriptional activator Myb & Not analyzed & Northern blot & Up & [62] \\
\hline MYC* & Myc proto-oncogene protein & Yes & EMSA & Up & {$[4]$} \\
\hline MYCBP* & c-myc binding protein & Not analyzed & RGA & Up & [63] \\
\hline NOS2* & Nitric Oxide Synthase 2 & Yes & EMSA & Up & [64] \\
\hline NOTCH2 & NOTCH2 protein & Yes & EMSA, RGA w/ mutated reporter gene & Up & {$[65]$} \\
\hline NRCAM* & Neuronal cell adhesion molecule & Not analyzed & RGA & Up & {$[66]$} \\
\hline PLAU* & urokinase plasminogen activator & Yes & EMSA & Up & {$[67]$} \\
\hline PLAUR & $\begin{array}{l}\text { urokinase-type plasminogen activator } \\
\text { receptor }\end{array}$ & Not analyzed & - & Up & [48] \\
\hline PPARD* & PPARdelta & Yes & EMSA & Up & [7] \\
\hline S100A4 & Protein S100-A4 & Yes & $\begin{array}{l}\text { Chip, EMSA, RGA w/ mutated reporter } \\
\text { gene }\end{array}$ & Up & {$[68]$} \\
\hline S100A6 & Protein S100-A6 & Not analyzed & RGA & Up & [69] \\
\hline SGK1 & Serum/glucocorticoid-regulated kinase 1 & Yes & ChIP & Up & [70] \\
\hline SMC3 & $\begin{array}{l}\text { Structural maintenance of } \\
\text { chromosomes protein } 3\end{array}$ & Yes & EMSA, RGA w/ mutated reporter gene & Up & [71] \\
\hline SOX9* & Transcription factor Sox-9 & Not analyzed & Northern blot & Up & [72] \\
\hline SP5 & Transcription factor Sp5 & Yes & EMSA & Up & [73] \\
\hline $\begin{array}{l}\text { SRSF3 } \\
\text { (SRp20) }\end{array}$ & Serine/arginine-rich splicing factor 3 & Not & RGA & Up & [74] \\
\hline SUZ12 & Polycomb protein SUZ12 & Yes & ChIP, EMSA & Up & [75] \\
\hline TCF1* & Transcription factor 7 & Not analyzed & RGA & Up & {$[76]$} \\
\hline TIAM1* & TIAM-1 & Not analyzed & Northern blot & Up & [77] \\
\hline TN-C & Tenascin-C & Yes & ChIP & Up & [78] \\
\hline VEGF* & Vascular endothelial growth factor & Not analyzed & RGA & Up & {$[17]$} \\
\hline YAP & Yes-associated protein & Yes & ChIP & Up & [79] \\
\hline
\end{tabular}

Based on a PubMed search, we identified $66 \beta$-catenin target genes. Nusse et al. have previously reported 33 of these genes on their web site. (http://www.stanford.edu/group/nusselab/cgi-bin/wnt/target_genes; these genes are marked with an asterisk.). The gene and protein names follow the naming convention of the Swiss-Prot database (http://www.uniprot.org). A regulation of a given target gene by $\beta$-catenin had to be confirmed by chromatin immune precipitation (ChIP), electrophoretic mobility shift assay (EMSA), or reporter gene assays (RGA) with mutated TCF binding sites to be classified as "direct".

DLD1, SW480, and LS174T cells (193 genes). While DLD1 and SW480 cells both express a mutated form of $\mathrm{APC}$, they differ with respect to the underlying genetic disturbance: DLD1 cells show microsatellite instability (MSI), whereas SW480 cells are derived from a tumor with chromosomal instability (CIN). However, SW480 cells (CIN) share a lot of commonly regulated genes with LS174T cells (MSI), suggesting that other factors apart from genetic instability contribute to the observed differences in gene expression between DLD1 and SW480 cells. Looking at the mutational status, DLD1, SW480, and LS174T cells differ with respect to the status of the genes APC, PI3K, and TP53, but they are identical with respect to status of the genes KRAS and PTEN: DLD1 (APC: Mutant; TP53: WT; PI3K: Mutant; KRAS: Mutant; PTEN: WT), SW480 (APC: Mutant; TP53: Mutant; PI3K: WT; KRAS: Mutant; PTEN: WT), and LS174T cells (APC: WT; TP53: Mutant; PI3K: Mutant; KRAS: Mutant; PTEN: WT) $[82,83]$. 
A

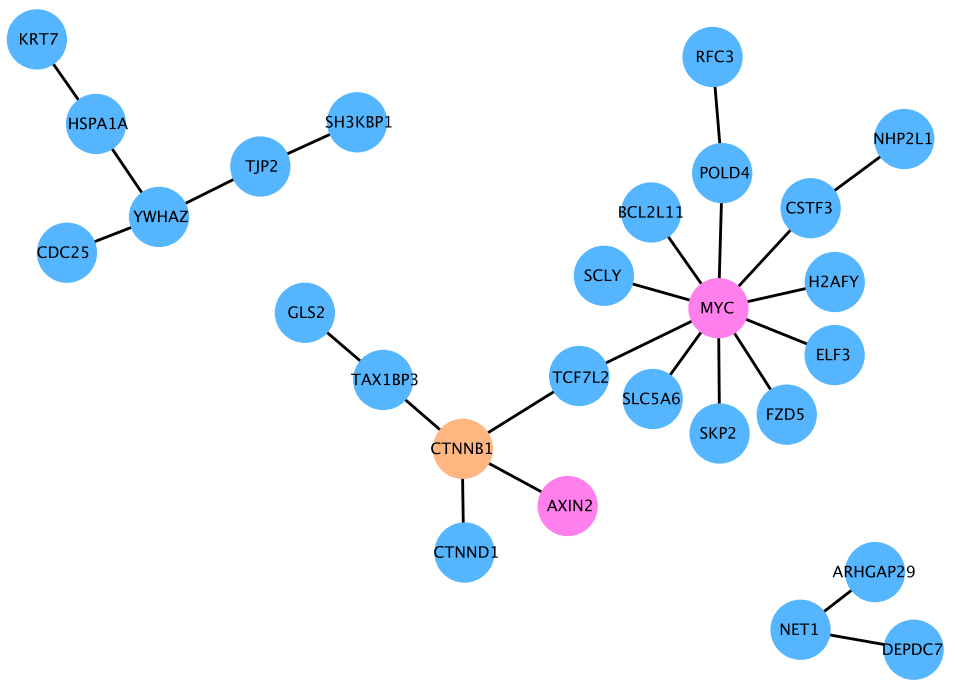

B

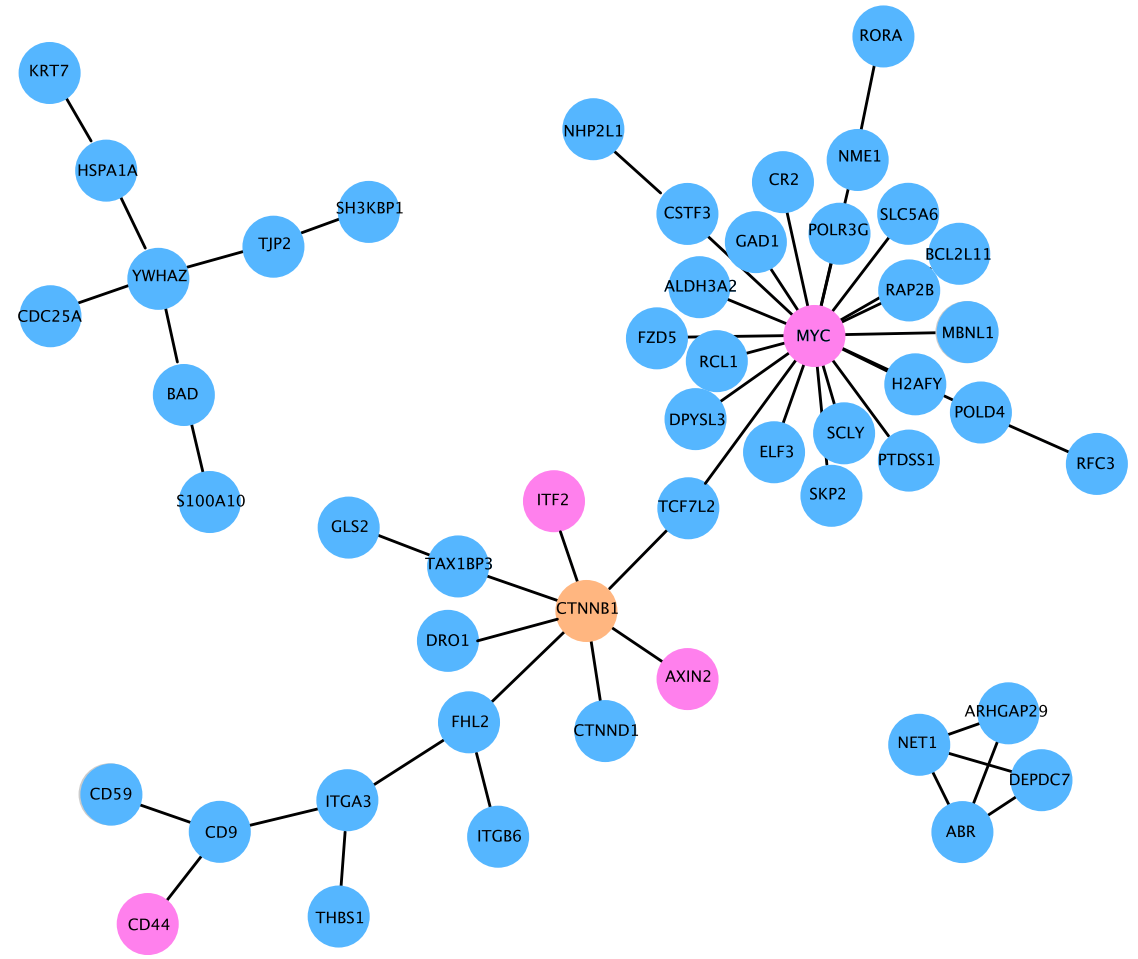

Figure 3 Identification of known interactions between differentially expressed $\beta$-catenin target genes in DLD1, SW480, and LS174T cells. Using the software package "Cytoscape" in combination with the "MiMI" plugin, we identified known interactions between the 193 differentially expressed $\beta$-catenin target genes in DLD1, SW480, and LS174T cells (A) and the 335 differentially expressed $\beta$-catenin target genes in DLD1 and SW480 cells (B). Only gene networks are displayed that contain three or more nodes. The genes highlighted in pink color have been previously described as $\beta$-catenin target genes (see Table 1).

Deregulation of PI3K/Akt signaling (as observed in DLD1 and LS174T) has been implicated in the phosphorylation of $\beta$-catenin at Ser552 [84], thereby promoting nuclear accumulation and enhancing $\beta$-catenin dependent transcriptional activity even in the absence of aberrant Wnt signaling [85,86]. This observation suggests that in particular LS174T cells that express wild- type APC could benefit from a mutation in the PI3K gene. But even DLD1 cells (with mutant APC) could profit from PI3K mutations: Deming et al. demonstrated that expression of a dominant active form of PI3K in $\mathrm{Apc}^{\mathrm{Min} /+}$ mice resulted in an increased tumor number and size and implicated the CCND1 gene as one transcriptional target that contributes to the observed phenotype of these mice 
Table 2 Identification of signaling pathways enriched in more than one cell line

\begin{tabular}{|c|c|c|c|}
\hline Treatment & Intersection & Enriched KEGG pathways & Biocarta pathways \\
\hline \multirow[t]{17}{*}{$\beta$-catenin RNAi } & DLD1/SW480 & Endocytosis & mCalpain pathway \\
\hline & & Insulin signaling pathway & CREB pathway \\
\hline & & Lysosome & IGF1R pathway \\
\hline & & FC gamma $R$ mediated phagocytosis & \\
\hline & & Apoptosis & \\
\hline & & Regulation of actin cytoskeleton & \\
\hline & & Glycerolipid metabolism & \\
\hline & & Focal adhesion & \\
\hline & & Aldosterone regulated sodium reabsorption & \\
\hline & DLD1/LS174T & PPAR signaling pathway & - \\
\hline & & Metabolism of xenobiotics by cytochrome P450 & \\
\hline & & Butanoate metabolism & \\
\hline & SW480/LS174T & Complement and coagulation cascades & \\
\hline & & Histidine metabolism & \\
\hline & & Ether lipid metabolism & \\
\hline & & NOD like receptor signaling pathway & \\
\hline & DLD1/SW480/LS174T & Steroid hormone biosynthesis & - \\
\hline \multirow[t]{14}{*}{$\beta$-galactosidase RNAi } & DLD1/SW480 & Glycine serine and threonine metabolism & - \\
\hline & & Renin angiotensin system & \\
\hline & DLD1/LS174T & DNA replication & ATRBRCA pathway \\
\hline & & Base excision repair & \\
\hline & & Mismatch repair & \\
\hline & & Homologous recombination & \\
\hline & & Cell cycle & \\
\hline & & Nucleotide excision repair & \\
\hline & & Pyrimidine metabolism & \\
\hline & & RNA polymerase & \\
\hline & & RNA degradation & \\
\hline & & Spliceosome & \\
\hline & SW480/LS174T & Basal cell carcinoma & - \\
\hline & DLD1/SW480/LS174T & - & \\
\hline
\end{tabular}

Gene set enrichment analyses were performed after treatment of DLD1, SW480, and LS174T cells with $\beta$-catenin RNAi or $\beta$-galactosidase RNAi using the KEGG and the Biocarta pathway database, respectively. Pathways that were enriched in more than one cell line were identified using a Biovenn software package.

[87]. In our experiments, CCND1 mRNA expression levels were up regulated in LS174T cells, but not in DLD1 cells.

The tumor suppressor p53 has been implicated in down-regulating $\beta$-catenin expression and/or activity by Siah-1 dependent (and GSK-3 $\beta$ independent) degradation $[88,89]$, reduction of TCF4 mRNA and protein levels [90] as well as reduction of $\beta$-catenin mRNA by p53 dependent regulation of miRNA miR-34 [91]. Accordingly, inactivation of the transcriptional activity of p53 by mutations -as observed in SW480 cells- should result in increased $\beta$-catenin mRNA and protein levels and transcriptional activity as well as increased mRNA and protein levels of TCF4 (TCF7L2). Interestingly,
LS174T cells showed a strong increase in the fold change value for CTNNB1 (encoding $\beta$-catenin) $(4,56$ versus 1,59 (DLD1) and 1,18 (SW480), respectively). All three cell lines showed slightly reduced fold change values for TCF4 (TCF7L2). The effect of p53 inactivation on the development of intestinal adenomas was also analyzed in $A p c^{\mathrm{Min} /+}$ mice: Despite the fact that $\mathrm{p} 53$ protein expression is deregulated as a consequence of APC loss (and probably other factors) and p53 is known to regulate $\beta$-catenin expression via a negative feedback loop, loss of p53 did not promote the initial steps of intestinal neoplasia in $A p c^{\mathrm{Min} /+}$ mice [92], suggesting that p53 has only a limited role in this mouse model. 
Apart from regulating $\beta$-catenin protein expression levels via proteasomal degradation, (nuclear) APC has been implicated in affecting $\beta$-catenin activity by recruiting co-repressors of $\beta$-catenin to promoter regions, as well as sequestering and enhancing the nuclear export of $\beta$ catenin [93-96]. Mutated forms of APC still show a nuclear localization, but they are more frequently observed in the cytoplasm when compared to wild-type APC, suggesting that mutation of APC is not only contributing to higher $\beta$-catenin protein expression levels, but also contribute to enhanced $\beta$-catenin activity [97]. When Zeineldin et al. generated mice expressing APC with mutated nuclear localization signals (mNLS) and compared these $A p c^{\mathrm{mNLS} / \mathrm{mNLS}}$ mice with $A p c^{+/+}$mice, they found up regulation of the mRNA for the genes AXIN2, MYC, and CCDN1 as well as down regulation of HATH1 mRNA in response to stimulation with Wnt [98]. Accordingly, we expected an increase in the fold change values for AXIN2, MYC, and CCDN1 transcripts as well as a reduction of HATH1 transcripts in DLD1 and SW480 cells (APC mutated) compared to LS174T (APC wild-type). In our experiments, DLD1 and SW480 showed a modest increase in the fold change values for MYC (see Additional file 1, tab "DLD1_SW480_LS174T_only") compared to LS174T cells. However, LS174T (and SW480) cells responded with a higher fold change for AXIN2 compared to DLD1 cells. CCND1 transcript levels were increased only in LS174T cells, whereas HATH1 transcript levels did not changed in any of three cell lines.

The differential expression of the genes AXIN2 and CCND1 in the three colorectal cancer cell lines highlights the fact that the genetic background of a given cell has a major impact on the expression of a specific gene. However, linking a specific somatic mutation in a tumor suppressor gene or proto oncogene, e.g. APC, PI3K, or TP53, to these differences in expression is difficult because the expression of a specific gene is affected by multiple transcription factors (along with their cofactors and corepressors). Therefore, we are not able to attribute the observed differences in the gene expression profiles for DLD1 and SW480 to a single mutation.

Compared to LS174T cells, the total number of differentially regulated $\beta$-catenin target genes was much lower in DLD1 and SW480 cells. This could be either specific to the genetic background of the cell lines used or due to different experimental approaches. While we transiently transfected DLD1 and SW480 cells with $\beta$-catenin siRNA and analyzed the gene expression 48 hours after transfection, Mokry et al. [99] stably transfected LS174T cells with a doxycycline inducible expression vector encoding $\beta$-catenin shRNA and stimulated the cells for 72 hours with doxycycline before analyzing the gene expression profile. Both research groups used Affymetrix Human Genome U133 Plus 2.0 DNA microarrays for their experiments. The longer incubation period used to identify potential $\beta$-catenin target genes in LS174T cells might contribute to secondary effects like the differential expression of indirect $\beta$-catenin target genes, thus explaining why the absolute number of differentially regulated genes was higher in LS174T cells when compared to DLD1 and SW480 cells. For this reason, we were particularly interested in genes that are up and down regulated in the non-isogenic colorectal cancer cell lines DLD1 and SW480 or DLD1, SW480, and LS174T cells, assuming that these genes are commonly and directly regulated by $\beta$-catenin.

Remarkably, the number of $\beta$-catenin regulated genes was very similar in the three cell lines when focusing on the list of 66 previously described $\beta$-catenin target genes. Here, DLD1, SW480 and LS174T cells differentially regulated 21, 30 and 34 of these genes, respectively. There are at least two reasons why the number of detected $\beta$-catenin target genes did not include (almost) all $66 \beta$-catenin target genes presented in Table 1 . First, the detection of $\beta$ catenin target genes is dependent on the cellular context. DLD1, SW480, and LS174T represent colorectal cancer cell lines. Therefore, the expression pattern of $\beta$-catenin target genes in these cells is likely to differ from $\beta$-catenin target genes found in healthy colon cells, colonic adenomas, or metastatic colonic cells that are also listed in Table 1. Second, the gene expression profile was analyzed 48 and 72 hours after beginning with the RNAi treatment, respectively. Different periods of time influence the identification of $\beta$-catenin target genes as well, since some of these genes might be regulated only for a short period of time immediately after induction of $\beta$-catenin activity. This phenomenon has been described by Van de Wetering et al. (2002): They transfected LS174T cells with doxycycline (Dox) inducible expression vectors encoding dnTCFs and analyzed the changes in gene expression using DNA microarrays. $11 \mathrm{~h}$ after treatment with Dox, 2411 genes where differentially regulated. After an incubation period of $23 \mathrm{~h}$, they identified 1199 differentially regulated genes. Comparison of the two sets of genes revealed that the expression of 1971 genes was abrogated between 11 and $23 \mathrm{~h}$ after Dox treatment, while 759 additional genes appeared in this time frame [62]. Similarly, another group analyzed the gene expression profiles of several known $\beta$ catenin target genes in a time-course experiment and classified these genes according to their expression profiles [100]. Based on this criterion, they identified genes that were "immediately up (or down) regulated", "early up (down)", or "late up (down)" in response to the activation of the Wnt/ $\beta$-catenin signaling cascade. When comparing their results to the regulation of the same genes in different cellular contexts, this group found that the regulation of these genes was similar, but not necessarily identical in different cell lines. This observation suggests that the 
expression levels and activities of a given transcription factor and its cofactors (or co-repressors) influence the starting point and duration of the gene expression of a specific target gene. Therefore, it is recommendable to identify target genes of a given transcription factor in different cell lines at least at the same time points, better yet in a timecourse experiment.

Using the KEGG pathway database, we identified 11 signaling pathways or cellular functions in DLD1 and SW480 cells that are differentially regulated in response to treatment of the colorectal cancer cell lines with $\beta$-catenin siRNA. In addition, the steroid hormone biosynthesis pathway was similarly regulated in all three cell lines analyzed. Whereas the steroid hormone biosynthesis pathway $[101,102]$ as well as the endocytosis pathway [103,104], the insulin signaling pathway [105,106], apoptosis [107,108], regulation of the actin cytoskeleton [49], and focal adhesion [109], have been associated with Wnt/ $\beta$-catenin signaling, there are no publications in the PubMed database linking $\beta$-catenin to the remaining six pathways in colorectal cancer cells. Interestingly, the list of KEGG pathways/functions did not include the canonical Wnt signaling pathway. This was probably due to the definition of the "KEGG Wnt signaling pathway" that summarized the canonical, the planar cell polarity (PCP), and the $\mathrm{Wnt} / \mathrm{Ca}^{2+}$ signaling pathway under one database entry, despite different functions of these signaling pathways. While the canonical Wnt pathway has been implicated in regulating the activity of the $\beta$ catenin protein, PCP signaling results in remodeling of the cytoskeleton that is a prerequisite for migration and cell polarization via the GTPases RHOA and RAC1. Wnt/Ca ${ }^{2+}$ signaling, however, plays a role in the regulation of cell adhesion and cell movements during gastrulation and results in the activation of protein kinase (PKC), calcium calmodulin mediated kinase II (CAMKII) and calcineurin [110].

Furthermore, all three Biocarta pathways that were enriched in DLD1 and SW480 cells have been associated with Wnt/ $\beta$-catenin signaling based on PubMed publications: the m-calpain pathway $[111,112]$, the Creb pathway $[26,113]$, and the IGF1R pathway $[114,115]$.

Since 6 out of the 66 previously described $\beta$-catenin target genes encode proteins that belong to the bHLH protein family (Table 1), we focused our analysis on this group of genes. Our analysis revealed that the genes ASCL2, ID1, ITF2, and MYC were regulated in a $\beta$-catenin dependent manner in DLD1 and SW480 cells. Interestingly, the proteins ASCL2 and ITF-2B as well as ID1 and ITF-2B are known to interact with each other $[116,117]$, suggesting that these bHLH proteins form a functional network in colorectal carcinoma cells.

\section{Conclusions}

In conclusion, by comparing potential $\beta$-catenin target genes in DLD1 and SW480 cells with 1) corresponding data from LS174T cells and 2) a list of previously identified $\beta$-catenin target genes, we found and confirmed a large number of $\beta$-catenin target genes, suggesting that DLD1 and SW480 (as well as LS174T cells) are suitable for identifying $\beta$-catenin target genes as well as $\beta$ catenin dependent signaling pathways and functions. Therefore, the presented list of commonly regulated genes in DLD1 and SW480 cells as well as the annotated list of previously published $\beta$-catenin target genes are useful resources for further studies.

\section{Methods}

\section{Cell culture}

The colon carcinoma cell lines DLD1 and SW480 were obtained from ATCC (Manassas, VA, USA) and were cultured in DMEM medium supplemented with $10 \%$ calf serum (PAA, Pasching, Austria). Short interfering RNAs targeting $\beta$-catenin (cat. no. D-003482-04) and $\beta$ galactosidase (cat. no. D-012539-01) were purchased from Dharmacon (Lafayette, CO, USA) as siGenome siRNAs. Cells were transfected with these siRNAs using Lipofectamine 2000 (Invitrogen, Carlsbad, CA, USA).

\section{Immuno detection}

Cell lysates were prepared with reporter gene lysis buffer (Promega, Mannheim, Germany) supplemented with protease inhibitor cocktail I (Calbiochem, Darmstadt, Germany). Equal amounts of protein were mixed with $2 \times$ SDS loading buffer (0.35 M Tris, $\mathrm{pH} 6.8 ; 30 \%$ (v/v) glycerol; 10\% (w/v) SDS; 100 mM Dithiothreitol; 0.01\% (w/v) bromphenol blue), separated by electrophoresis in discontinuous SDS-polyacrylamide gels and transferred to Immobilon-P membranes (Millipore, Billerica, MA, USA). Antibodies specific for $\beta$-catenin (BD Transduction Labs, San Jose, CA, USA), $\beta$-actin (MP Biomedicals, Eschwege, Germany) and the secondary horseradish peroxidaseconjugated goat anti-mouse antibody (GE Healthcare, Freiburg, Germany) were used for immuno detection. Blots were subjected to Supersignal West Dura chemiluminescence substrate (Thermo Scientific, Rockford, IL, USA) and exposed to Fuji Medical x-ray film SuperRX (FujiFilm).

\section{Reporter gene assays}

For reporter gene assays, $10^{5}$ DLD1 or SW480 cells were seeded per well (12 well plate). Cells were transfected with the indicated siRNAs using Lipofectamine 2000 (Life Technologies). 24 hours later, the $8 \times$ TOPflash reporter gene construct (a generous gift from Randall $\mathrm{T}$. Moon, University of Washington) as well as the plasmid pCH110 encoding $\beta$-galactosidase (GE Healthcare, Freiburg, Germany) were transfected into these cells. 72 hours after the siRNA transfection, cells were harvested, lysed with reporter lysis buffer (Promega) and luciferase 
activities were measured using a luciferase assay reagent (Promega) and a luminometer (Orion II, Berthold Detection Systems, Wildbad, Germany). $\beta$-galactosidase activity was determined by standard methods using oNitrophenyl $\beta$-D-galactopyranoside (ONPG, Sigma-Aldrich, Taufkirchen, Germany) as a control for transfection efficiency.

\section{Microarray analysis}

DLD1 and SW480 cells were harvested $48 \mathrm{~h}$ after siRNA transfection using TRIzol (Life Technologies, Darmstadt, Germany). Total RNA was isolated according to the manufacturer's instructions and reverse transcribed using SuperScript II reverse transcriptase (Life Technologies) according to the instructions provided by the manufacturer. cDNA was amplified and labeled with biotin using kits from Affymetrix. Labeled probes were hybridized to Human Genome U133 Plus 2.0 microarrays (Affymetrix), washed, stained and scanned using equipment from Affymetrix. The microarray analysis was performed in triplicates for each cell line (see also the corresponding CEL files that are part of the accompanying GEO submission).

\section{Identification of validated $\beta$-catenin target genes}

We were particularly interested in $\beta$-catenin target genes that are regulated in normal colon or colon carcinoma cells or colon carcinoma cell lines. For this reason, the PubMed database was searched using the phrase "beta catenin AND target AND (colorectal OR colon OR intestinal OR intestine)". 591 articles were identified (as of June $1^{\text {st }}, 2012$ ) and publications were screened for the identification and characterization of $\beta$-catenin target genes. We were able to identify 66 published $\beta$-catenin target genes that matched our criteria (Table 1). 33 out of the 66 genes have been published earlier by Nusse et al. on their web site http://www.stanford.edu/group/ nusselab/cgi-bin/wnt/target_genes (last update: October 2010). These genes are marked with an asterisk after the gene name (Table 1 ).

\section{Statistical analysis}

For evaluation purposes, we compared genes differentially expressed in DLD1 and SW480 cells after treatment with $\beta$-catenin siRNA to a previously published data set containing differentially expressed genes after treatment of the colon carcinoma cell line LS174T with $\beta$-catenin shRNA (http://www.ncbi.nlm.nih.gov/geo/query/acc.cgi? acc=GSE18560). The software package $\mathrm{R}$ (version 2.14.1) was used for the statistical analysis of the microarray data. Microarray data were preprocessed using the rma function from the R package "affy". The expression matrix was filtered to contain only those probe sets that can be assigned to a gene name. $\log 2$ intensity values were used for all subsequent analyses. Differentially expressed genes were identified with the R package "limma". Genes were called "differentially expressed" if the corrected $\mathrm{p}$ value (according to Benjamini-Hochberg) was lower than 0.05. We considered a gene to be significant only if all of its significant probe sets were regulated in the same direction. Genes with significant probe sets that were differently regulated were not considered significant because we could not determine if the gene is up- or down regulated.

\section{Gene set enrichment analysis (GSEA)}

The gene set enrichment analysis was performed using the GSEA software $[80,81]$. Due to the small sample size of our data sets, we used gene set permutation for the GSEA analysis. Probe sets belonging to the same gene were collapsed to a gene symbol and 1000 permutations were performed to find differentially expressed gene sets. If our data sets contained less than 15 genes of a certain gene set, the gene set was filtered out. After this restriction, 138 out of 217 Biocarta gene sets and 175 out of 186 KEGG gene sets were analyzed. Gene sets with a false discover rate (FDR) lower than 0.25 were considered statistically significant. The corresponding files containing the data of the GSEA analysis are part of the Additional files. The names of the directories containing the files were composed of the term 'GSEA', the name of the cell line, e.g. DLD1, SW480, or LS174T, and the pathway database (KEGG or Biocarta). Please use the files with the name 'index.html' in the corresponding directories to start exploring the data.

KEGG and Biocarta pathways that are regulated similarly in two or three cell lines were identified using the Biovenn software (http://www.cmbi.ru.nl/cdd/biovenn/) [118].

\section{Network visualization}

Gene symbols of $\beta$-catenin target genes common to two or more cell lines were entered in the query function of the "Michigan molecular interaction" (MiMI) plugin (version 3.11) in the software package "Cytoscape" (version 2.83) [119,120]. Using the human database entries to analyze interactions between all molecule types and in all data sources, we searched for "Interactions among query genes". Only networks that contained three or more nodes were displayed.

\section{Availability of supporting data}

The data sets supporting the results of this article are available NCBI's Gene Expression Omnibus (GEO) repository [121]. The unique identifier for this dataset is GSE44097. The corresponding information can be found at the following web site: http://www.ncbi.nlm.nih.gov/ geo/query/acc.cgi?acc=GSE44097. 


\section{Additional files}

Additional file 1: Table S1. Results of the DNA microarray analysis (all genes). DLD1, SW480, and LS174T cells were treated with siRNA or shRNA targeting beta-catenin. Differentially expressed genes were identified using DNA microarrays as described in Materials and Methods. Using the Biovenn software, genes that are regulated similarly in two or three cell lines were identified and listed under separate tabs. Accordingly, genes that are differentially expressed in only one cell line were listed in a separate tab labeled with the name of the cell line.

Additional file 2: Table S2. Results of the DNA microarray analysis (focusing on known $\beta$-catenin target genes). DLD1, SW480, and LS174T cells were treated with siRNA or shRNA targeting $\beta$-catenin. Microarray data was re-analyzed focusing our analysis only on the list of these 66 previously published $\beta$-catenin target genes. Using the Biovenn software, genes that are regulated similarly in two or three cell lines were identified and listed under separate tabs. Accordingly, genes that are differentially expressed in only one cell line were listed in a separate tab labeled with the name of the cell line.

Additional file 3: Table S3. Results of the DNA microarray analysis (focusing on genes encoding bHLH proteins). DLD1, SW480, and LS174T cells were treated with siRNA or shRNA targeting beta-catenin. Microarray data was re-analyzed focusing our analysis only on the $96 \mathrm{bHLH}$ proteins listed in the PFAM database. Using the Biovenn software, genes that are regulated similarly in two or three cell lines were identified and listed under separate tabs. Accordingly, genes that are differentially expressed in only one cell line were listed in a separate tab labeled with the name of the cell line.

\section{Additional file 4: GSEA analysis using the Biocarta pathway}

database. This zipped file contains confirming data of the GSEA analysis. The names of the directories containing the files were composed of the term 'GSEA', the name of the cell line, e.g. DLD1, SW480, or LS174T, and the pathway database (Biocarta). Please use a web browser to view the files with the name 'index.html' in the corresponding directories to start exploring the data.

Additional file 5: GSEA analysis using the KEGG pathway database. This zipped file contains confirming data of the GSEA analysis. The names of the directories containing the files were composed of the term 'GSEA', the name of the cell line, e.g. DLD1, SW480, or LS174T, and the pathway database (KEGG). Please use a web browser to view the files with the name 'index.html' in the corresponding directories to start exploring the data.

\section{Competing interests}

The authors declare that they have no competing interests.

\section{Authors' contributions}

$\mathrm{AH}$ analyzed the data, generated the figures and drafted the manuscript. VJ performed the statistical analysis. ST and SK performed the DNA microarray experiment. HB, BG and FTK participated in the design and coordination of the study. All authors read and approved the final manuscript.

\section{Acknowledgements}

This project was supported by the grant KO1826/5 to F.T.K. by the German Research Council (DFG).

\section{Author details}

${ }^{1}$ Department of Medicine II, University of Munich, Marchioninistrasse 15, 81377 Munich, Germany. ${ }^{2}$ Institute for Medical Informatics, Biometry and Epidemiology, 81377 Munich, Germany. ${ }^{3}$ Laboratory for Functional Genome Analysis (LAFUGA), Gene Center, University of Munich, 81377 Munich, Germany.

Received: 28 March 2013 Accepted: 17 January 2014

Published: 28 January 2014

\section{References}

1. Barker N, Clevers H: Mining the Wnt pathway for cancer therapeutics. Nat rev Drug discov 2006, 5:997-1014.
2. Vogelstein B, Fearon ER, Kern SE, Hamilton SR, Preisinger AC, Nakamura Y, White R: Allelotype of colorectal carcinomas. Science 1989, 244:207-211.

3. Powell SM, Zilz N, Beazer-Barclay Y, Bryan TM, Hamilton SR, Thibodeau SN, Vogelstein B, Kinzler KW: APC mutations occur early during colorectal tumorigenesis. Nature 1992, 359:235-237.

4. He TC, Sparks AB, Rago C, Hermeking H, Zawel L, da Costa LT, Morin PJ, Vogelstein B, Kinzler KW: Identification of c-MYC as a target of the APC pathway. Science 1998, 281:1509-1512.

5. Tetsu O, McCormick F: Beta-catenin regulates expression of cyclin D1 in colon carcinoma cells. Nature 1999, 398:422-426.

6. Shtutman M, Zhurinsky J, Simcha I, Albanese C, D'Amico M, Pestell R, Ben-Ze'ev A: The cyclin D1 gene is a target of the beta-catenin/LEF-1 pathway. Proc Natl Acad Sci USA 1999, 96:5522-5527.

7. He TC, Chan TA, Vogelstein B, Kinzler KW: PPARdelta is an APC-regulated target of nonsteroidal anti-inflammatory drugs. Cell 1999, 99:335-345.

8. Jubb AM, Chalasani S, Frantz GD, Smits R, Grabsch HI, Kavi V, Maughan NJ, Hillan KJ, Quirke P, Koeppen H: Achaete-scute like 2 (ascl2) is a target of Wnt signalling and is upregulated in intestinal neoplasia. Oncogene 2006, 25:3445-3457.

9. Yamada T, Takaoka AS, Naishiro Y, Hayashi R, Maruyama K, Maesawa C, Ochiai A, Hirohashi S: Transactivation of the multidrug resistance 1 gene by $\mathrm{T}$-cell factor $4 /$ beta-catenin complex in early colorectal carcinogenesis. Cancer Res 2000, 60:4761-4766.

10. Kim PJ, Plescia J, Clevers H, Fearon ER, Altieri DC: Survivin and molecular pathogenesis of colorectal cancer. Lancet 2003, 362:205-209.

11. Rockman SP, Currie SA, Ciavarella M, Vincan E, Dow C, Thomas RJ, Phillips WA: Id2 is a target of the beta-catenin/T cell factor pathway in colon carcinoma. J Biol Chem 2001, 276:45113-45119.

12. Willert J, Epping M, Pollack JR, Brown PO, Nusse R: A transcriptional response to Wht protein in human embryonic carcinoma cells. BMC Dev Biol 2002, 2:8.

13. Fujita M, Furukawa Y, Tsunoda T, Tanaka T, Ogawa M, Nakamura Y: Upregulation of the ectodermal-neural cortex 1 (ENC1) gene, a downstream target of the beta-catenin/T-cell factor complex, in colorectal carcinomas. Cancer Res 2001, 61:7722-7726.

14. Crawford HC, Fingleton BM, Rudolph-Owen LA, Goss KJ, Rubinfeld B, Polakis P, Matrisian LM: The metalloproteinase matrilysin is a target of beta-catenin transactivation in intestinal tumors. Oncogene 1999, 18:2883-2891.

15. Brabletz T, Jung A, Dag S, Hlubek F, Kirchner T: Beta-catenin regulates the expression of the matrix metalloproteinase-7 in human colorectal cancer. Am J Pathol 1999, 155:1033-1038.

16. Hlubek F, Spaderna S, Jung A, Kirchner T, Brabletz T: Beta-catenin activates a coordinated expression of the proinvasive factors laminin- 5 gamma 2 chain and MT1-MMP in colorectal carcinomas. Int J Cancer 2004, 108:321-326.

17. Zhang X, Gaspard JP, Chung DC: Regulation of vascular endothelial growth factor by the Wnt and K-ras pathways in colonic neoplasia. Cancer Res 2001, 61:6050-6054.

18. Cisse B, Caton ML, Lehner M, Maeda T, Scheu S, Locksley R, Holmberg D, Zweier C, den Hollander NS, Kant SG, Holter W, Rauch A, Zhuang Y, Reizis B: Transcription factor E2-2 is an essential and specific regulator of plasmacytoid dendritic cell development. Cell 2008, 135:37-48.

19. Leow CC, Romero MS, Ross S, Polakis P, Gao W-Q: Hath1, down-regulated in colon adenocarcinomas, inhibits proliferation and tumorigenesis of colon cancer cells. Cancer Res 2004, 64:6050-6057.

20. Kolligs FT, Nieman MT, Winer I, Hu G, Van Mater D, Feng Y, Smith IM, Wu R, Zhai $Y$, Cho KR, Fearon ER: ITF-2, a downstream target of the Wnt/TCF pathway, is activated in human cancers with beta-catenin defects and promotes neoplastic transformation. Cancer Cell 2002, 1:145-155.

21. Massari ME, Murre C: Helix-loop-helix proteins: regulators of transcription in eucaryotic organisms. Mol Cell Biol 2000, 20:429-440.

22. Langlands K, Yin X, Anand G, Prochownik EV: Differential interactions of Id proteins with basic-helix-loop-helix transcription factors. J Biol Chem 1997, 272:19785-19793.

23. Heinen CD, Richardson D, White $R$, Groden J: Microsatellite instability in colorectal adenocarcinoma cell lines that have full-length adenomatous polyposis coli protein. Cancer Res 1995, 55:4797-4799.

24. Ilyas M, Tomlinson IP, Rowan A, Pignatelli M, Bodmer WF: Beta-catenin mutations in cell lines established from human colorectal cancers. Proc Natl Acad Sci USA 1997, 94:10330-10334.

25. Gavert N, Sheffer M, Raveh S, Spaderna S, Shtutman M, Brabletz T, Barany F, Paty P, Notterman D, Domany E, Ben-Ze'ev A: Expression of L1-CAM and 
ADAM10 in human colon cancer cells induces metastasis. Cancer Res 2007, 67:7703-7712.

26. Iseki H, Takeda A, Andoh T, Takahashi N, Kurochkin IV, Yarmishyn A, Shimada H, Okazaki Y, Koyama I: Human Arm protein lost in epithelial cancers, on chromosome $X 1$ (ALEX1) gene is transcriptionally regulated by CREB and Wnt/beta-catenin signaling. Cancer Sci 2010, 101:1361-1366.

27. Yan D, Wiesmann M, Rohan M, Chan V, Jefferson AB, Guo L, Sakamoto D, Caothien RH, Fuller JH, Reinhard C, Garcia PD, Randazzo FM, Escobedo J, Fantl WJ, Williams LT: Elevated expression of axin2 and hnkd mRNA provides evidence that Wnt/beta -catenin signaling is activated in human colon tumors. Proc Natl Acad Sci USA 2001, 98:14973-14978.

28. Lustig B, Jerchow B, Sachs M, Weiler S, Pietsch T, Karsten U, van de Wetering M, Clevers H, Schlag PM, Birchmeier W, Behrens J: Negative feedback loop of Wnt signaling through upregulation of conductin/ axin2 in colorectal and liver tumors. Mol Cell Biol 2002, 22:1184-1193.

29. Jho E-H, Zhang T, Domon C, Joo C-K, Freund J-N, Costantini F: Wnt/betacatenin/Tcf signaling induces the transcription of Axin2, a negative regulator of the signaling pathway. Mol Cell Biol 2002, 22:1172-1183.

30. Sekiya T, Adachi S, Kohu K, Yamada T, Higuchi O, Furukawa Y, Nakamura Y, Nakamura T, Tashiro K, Kuhara S, Ohwada S, Akiyama T: Identification of BMP and activin membrane-bound inhibitor (BAMBI), an inhibitor of transforming growth factor-beta signaling, as a target of the betacatenin pathway in colorectal tumor cells. J Biol Chem 2004 279:6840-6846.

31. Lapham A, Adams JE, Paterson A, Lee M, Brimmell M, Packham G: The $\mathrm{BCl}-\mathrm{w}$ promoter is activated by beta-catenin/TCF4 in human colorectal carcinoma cells. Gene 2009, 432:112-117.

32. Yu T, Chen X, Zhang W, Colon D, Shi J, Napier D, Rychahou P, Lu W, Lee EY, Weiss HL, Evers BM, Liu C: Regulation of the potential marker for intestinal cells, Bmi1, by $\beta$-catenin and the zinc finger protein KLF4 implications for colon cancer. J Biol Chem 2012, 287:3760-3768.

33. Kim J-S, Crooks H, Dracheva T, Nishanian TG, Singh B, Jen J, Waldman T: Oncogenic beta-catenin is required for bone morphogenetic protein 4 expression in human cancer cells. Cancer Res 2002, 62:2744-2748.

34. Wielenga VJ, Smits R, Korinek V, Smit L, Kielman M, Fodde R, Clevers H, Pals ST: Expression of CD44 in Apc and Tcf mutant mice implies regulation by the WNT pathway. Am J Pathol 1999, 154:515-523.

35. Zeilstra J, Joosten SPJ, Dokter M, Verwiel E, Spaargaren M, Pals ST: Deletion of the WNT target and cancer stem cell marker CD44 in Apc(Min/+) mice attenuates intestinal tumorigenesis. Cancer Res 2008, 68:3655-3661.

36. Wassermann S, Scheel SK, Hiendlmeyer E, Palmqvist R, Horst D, Hlubek F, Haynl A, Kriegl L, Reu S, Merkel S, Brabletz T, Kirchner T, Jung A: p16INK4a is a beta-catenin target gene and indicates low survival in human colorectal tumors. Gastroenterology 2009, 136:196-205. e2.

37. Domon-Dell C, Freund J-N: Stimulation of Cdx1 by oncogenic betacatenin/Tcf4 in colon cancer cells; opposite effect of the CDX2 homeoprotein. FEBS Lett 2002, 518:83-87.

38. Miwa N, Furuse M, Tsukita S, Niikawa N, Nakamura Y, Furukawa Y: Involvement of claudin-1 in the beta-catenin/Tcf signaling pathway and its frequent upregulation in human colorectal cancers. Oncol Res 2001, 12:469-476.

39. Araki Y, Okamura S, Hussain SP, Nagashima M, He P, Shiseki M, Miura K, Harris CC: Regulation of cyclooxygenase-2 expression by the Wnt and ras pathways. Cancer Res 2003, 63:728-734.

40. Niida A, Hiroko T, Kasai M, Furukawa Y, Nakamura Y, Suzuki Y, Sugano S, Akiyama T: DKK1, a negative regulator of Wnt signaling, is a target of the beta-catenin/TCF pathway. Oncogene 2004, 23:8520-8526.

41. Pendás-Franco N, García JM, Peña C, Valle N, Pálmer HG, Heinäniemi M, Carlberg C, Jiménez B, Bonilla F, Muñoz A, González-Sancho JM: DICKKOPF-4 is induced by TCF/beta-catenin and upregulated in human colon cancer, promotes tumour cell invasion and angiogenesis and is repressed by 1alpha,25-dihydroxyvitamin D3. Oncogene 2008, 27:4467-4477.

42. Baehs S, Herbst A, Thieme SE, Perschl C, Behrens A, Scheel S, Jung A Brabletz T, Göke B, Blum H, Kolligs FT: Dickkopf-4 is frequently downregulated and inhibits growth of colorectal cancer cells. Cancer Lett 2009, 276:152-159.

43. Campbell PM, Szyf M: Human DNA methyltransferase gene DNMT1 is regulated by the APC pathway. Carcinogenesis 2003, 24:17-24.

44. Kim TH, Xiong $H$, Zhang $Z$, Ren B: Beta-Catenin activates the growth factor endothelin-1 in colon cancer cells. Oncogene 2005, 24:597-604.

45. Batlle E, Henderson JT, Beghtel H, van den Born MMW, Sancho E, Huls G, Meeldijk J, Robertson J, van de Wetering M, Pawson T, Clevers H:
Beta-catenin and TCF mediate cell positioning in the intestinal epithelium by controlling the expression of EphB/ephrinB. Cell 2002, 111:251-263.

46. Shimokawa T, Furukawa Y, Sakai M, Li M, Miwa N, Lin Y-M, Nakamura Y: Involvement of the FGF18 gene in colorectal carcinogenesis, as a novel downstream target of the beta-catenin/T-cell factor complex. Cancer Res 2003, 63:6116-6120.

47. Ray R, Cabal-Manzano R, Moser AR, Waldman T, Zipper LM, Aigner A, Byers SW, Riegel AT, Wellstein A: Up-regulation of fibroblast growth factorbinding protein, by beta-catenin during colon carcinogenesis. Cancer Res 2003, 63:8085-8089

48. Mann B, Gelos M, Siedow A, Hanski ML, Gratchev A, llyas M, Bodmer WF, Moyer MP, Riecken EO, Buhr HJ, Hanski C: Target genes of beta-catenin-T cell-factor/lymphoid-enhancer-factor signaling in human colorectal carcinomas. Proc Natl Acad Sci USA 1999, 96:1603-1608.

49. Vignjevic D, Schoumacher M, Gavert N, Janssen K-P, Jih G, Laé M, Louvard $D$, Ben-Ze'ev A, Robine S: Fascin, a novel target of beta-catenin-TCF signaling, is expressed at the invasive front of human colon cancer Cancer Res 2007, 67:6844-6853.

50. Koh TJ, Bulitta CJ, Fleming JV, Dockray GJ, Varro A, Wang TC: Gastrin is a target of the beta-catenin/TCF-4 growth-signaling pathway in a model of intestinal polyposis. J Clin Invest 2000, 106:533-539.

51. Li Y, Bavarva JH, Wang Z, Guo J, Qian C, Thibodeau SN, Golemis EA, Liu W: HEF1, a novel target of Wnt signaling, promotes colonic cell migration and cancer progression. Oncogene 2011, 30:2633-2643.

52. Peignon G, Durand A, Cacheux W, Ayrault O, Terris B, Laurent-Puig P, Shroyer NF, Van Seuningen I, Honjo T, Perret C, Romagnolo B: Complex interplay between $\beta$-catenin signalling and Notch effectors in intestinal tumorigenesis. Gut 2011, 60:166-176.

53. Rodilla V, Villanueva A, Obrador-Hevia A, Robert-Moreno A, Fernández-Majada V, Grilli A, López-Bigas N, Bellora N, Albà MM, Torres F, Duñach M, Sanjuan X, Gonzalez S, Gridley T, Capella G, Bigas A, Espinosa L: Jagged 1 is the pathological link between Wnt and Notch pathways in colorectal cancer. Proc Natl Acad Sci USA 2009, 106:6315-6320.

54. Gavert N, Conacci-Sorrell M, Gast D, Schneider A, Altevogt P, Brabletz T, Ben-Ze'ev A: L1, a novel target of beta-catenin signaling, transforms cells and is expressed at the invasive front of colon cancers. J Cell Biol 2005, 168:633-642.

55. Hlubek F, Jung A, Kotzor N, Kirchner T, Brabletz T: Expression of the invasion factor laminin gamma2 in colorectal carcinomas is regulated by beta-catenin. Cancer Res 2001, 61:8089-8093.

56. Hovanes K, Li TW, Munguia JE, Truong T, Milovanovic T, Marsh Lawrence J, Holcombe RF, Waterman ML: Beta-catenin-sensitive isoforms of lymphoid enhancer factor- 1 are selectively expressed in colon cancer. Nat Genet 2001, 28:53-57.

57. Filali M, Cheng N, Abbott D, Leontiev V, Engelhardt JF: Wnt-3A/betacatenin signaling induces transcription from the LEF-1 promoter. J Biol Chem 2002, 277:33398-33410.

58. Li TW-H, Ting J-HT, Yokoyama NN, Bernstein A, van de Wetering M, Waterman $\mathrm{ML}$ : Wnt activation and alternative promoter repression of LEF1 in colon cancer. Mol Cell Biol 2006, 26:5284-5299.

59. Barker N, van Es JH, Kuipers J, Kujala P, van den Born M, Cozijnsen M, Haegebarth A, Korving J, Begthel H, Peters PJ, Clevers H: Identification of stem cells in small intestine and colon by marker gene Lgr5. Nature 2007, 449:1003-1007.

60. Najafov A, Seker T, Even I, Hoxhaj G, Selvi O, Ozel DE, Koman A, Birgül-lyison $\mathrm{N}$ : MENA Is a Transcriptional Target of the Wnt/Beta-Catenin Pathway. PLOS ONE 2012, 7:e37013.

61. Boon EMJ, van der Neut R, van de Wetering M, Clevers H, Pals ST: Wnt signaling regulates expression of the receptor tyrosine kinase met in colorectal cancer. Cancer Res 2002, 62:5126-5128.

62. van de Wetering M, Sancho E, Verweij C, de Lau W, Oving I, Hurlstone A, van der Horn K, Batlle E, Coudreuse D, Haramis AP, Tjon-Pon-Fong M, Moerer P, van den Born M, Soete G, Pals S, Eilers M, Medema R, Clevers H: The beta-catenin/TCF-4 complex imposes a crypt progenitor phenotype on colorectal cancer cells. Cell 2002, 111:241-250.

63. Jung H-C, Kim K: Identification of MYCBP as a beta-catenin/LEF-1 target using DNA microarray analysis. Life Sci 2005, 77:1249-1262.

64. Du Q, Park KS, Guo Z, He P, Nagashima M, Shao L, Sahai R, Geller DA, Hussain SP: Regulation of human nitric oxide synthase 2 expression by Wnt beta-catenin signaling. Cancer Res 2006, 66:7024-7031.

65. Ungerbäck J, Elander N, Grünberg J, Sigvardsson M, Söderkvist P: The Notch-2 gene is regulated by Wnt signaling in cultured colorectal cancer cells. PLOS ONE 2011, 6:e17957. 
66. Conacci-Sorrell ME, Ben-Yedidia $T$, Shtutman $M$, Feinstein $E$, Einat $P$, Ben-Ze'ev A: Nr-CAM is a target gene of the beta-catenin/LEF-1 pathway in melanoma and colon cancer and its expression enhances motility and confers tumorigenesis. Genes Dev 2002, 16:2058-2072.

67. Hiendlmeyer E, Regus S, Wassermann S, Hlubek F, Haynl A, Dimmler A, Koch C, Knoll C, van Beest M, Reuning U, Brabletz T, Kirchner T, Jung A: Betacatenin up-regulates the expression of the urokinase plasminogen activator in human colorectal tumors. Cancer Res 2004, 64:1209-1214.

68. Stein $U$, Arlt F, Walther W, Smith J, Waldman T, Harris ED, Mertins SD, Heizmann CW, Allard D, Birchmeier W, Schlag PM, Shoemaker RH: The metastasisassociated gene S100A4 is a novel target of beta-catenin/T-cell factor signaling in colon cancer. Gastroenterology 2006, 131:1486-1500.

69. Kilańczyk E, Graczyk A, Ostrowska H, Kasacka I, Leśniak W, Filipek A: S100A6 is transcriptionally regulated by $\beta$-catenin and interacts with a novel target, lamin A/C, in colorectal cancer cells. Cell Calcium 2012, 51:470-477.

70. Dehner M, Hadjihannas M, Weiske J, Huber O, Behrens J: Wnt signaling inhibits Forkhead box O3a-induced transcription and apoptosis through up-regulation of serum- and glucocorticoid-inducible kinase 1. J Biol Chem 2008, 283:19201-19210.

71. Ghiselli G, Coffee N, Munnery CE, Koratkar R, Siracusa LD: The cohesin SMC3 is a target the for beta-catenin/TCF4 transactivation pathway. J Biol Chem 2003, 278:20259-20267.

72. Blache $P$, van de Wetering M, Duluc I, Domon C, Berta P, Freund J-N, Clevers $H$, Jay P: SOX9 is an intestine crypt transcription factor, is regulated by the Wnt pathway, and represses the CDX2 and MUC2 genes. J Cell Biol 2004, 166:37-47

73. Takahashi M, Nakamura Y, Obama K, Furukawa Y: Identification of SP5 as a downstream gene of the beta-catenin/Tcf pathway and its enhanced expression in human colon cancer. Int J Oncol 2005, 27:1483-1487.

74. Gonçalves V, Matos P, Jordan P: The beta-catenin/TCF4 pathway modifies alternative splicing through modulation of SRp20 expression. RNA 2008, 14:2538-2549.

75. Kirmizis A, Bartley SM, Farnham PJ: Identification of the polycomb group protein $\mathrm{SU}(\mathrm{Z}) 12$ as a potential molecular target for human cancer therapy. Mol Cancer Ther 2003, 2:113-121.

76. Roose J, Huls G, van Beest M, Moerer P, van der Horn K, Goldschmeding R, Logtenberg T, Clevers $\mathrm{H}$ : Synergy between tumor suppressor APC and the beta-catenin-Tcf4 target Tcf1. Science 1999, 285:1923-1926.

77. Malliri A, Rygiel TP, van der Kammen RA, Song J-Y, Engers R, Hurlstone AFL, Clevers H, Collard JG: The rac activator Tiam 1 is a Wnt-resposive gene that modifies intestinal tumor development. J Biol Chem 2006, 281:543-548.

78. Beiter K, Hiendlmeyer E, Brabletz T, Hlubek F, Haynl A, Knoll C, Kirchner T: Jung $A$ : beta-Catenin regulates the expression of tenascin- $C$ in human colorectal tumors. Oncogene 2005, 24:8200-8204.

79. Konsavage WM, Kyler SL, Rennoll SA, Jin G, Yochum GS: Wnt/ß-catenin signaling regulates Yes-associated protein (YAP) gene expression in colorectal carcinoma cells. J Biol Chem 2012, 287:11730-11739.

80. Subramanian A, Tamayo P, Mootha VK, Mukherjee S, Ebert BL, Gillette MA, Paulovich A, Pomeroy SL, Golub TR, Lander ES, Mesirov JP: Gene set enrichment analysis: a knowledge-based approach for interpreting genome-wide expression profiles. Proc Natl Acad Sci USA 2005, 102:15545-15550.

81. Mootha VK, Lindgren CM, Eriksson K-F, Subramanian A, Sihag S, Lehar J, Puigserver $\mathrm{P}$, Carlsson E, Ridderstråle M, Laurila E, Houstis N, Daly MJ, Patterson N, Mesirov JP, Golub TR, Tamayo P, Spiegelman B, Lander ES, Hirschhorn JN, Altshuler D, Groop LC: PGC-1alpha-responsive genes involved in oxidative phosphorylation are coordinately downregulated in human diabetes. Nat Genet 2003, 34:267-273.

82. Buck E, Eyzaguirre A, Barr S, Thompson S, Sennello R, Young D, Iwata KK, Gibson NW, Cagnoni P, Haley JD: Loss of homotypic cell adhesion by epithelial-mesenchymal transition or mutation limits sensitivity to epidermal growth factor receptor inhibition. Mol Cancer Ther 2007, 6:532-541.

83. COSMIC: Cell Lines Project. [http://cancer.sanger.ac.uk/cancergenome/ projects/cell_lines/]

84. He XC, Yin T, Grindley JC, Tian Q, Sato T, Tao WA, Dirisina R, PorterWestpfahl KS, Hembree M, Johnson T, Wiedemann LM, Barrett TA, Hood L, Wu H, Li L: PTEN-deficient intestinal stem cells initiate intestinal polyposis. Nat Genet 2007, 39:189-198.

85. He XC, Zhang J, Tong W-G, Tawfik O, Ross J, Scoville DH, Tian Q, Zeng X, He $X$, Wiedemann LM, Mishina Y, Li L: BMP signaling inhibits intestinal stem cell self-renewal through suppression of Wnt-beta-catenin signaling. Nat Genet 2004, 36:1117-1121.
86. Persad S, Troussard AA, McPhee TR, Mulholland DJ, Dedhar S: Tumor suppressor PTEN inhibits nuclear accumulation of beta-catenin and T cell/lymphoid enhancer factor 1-mediated transcriptional activation. J Cell Biol 2001, 153:1161-1174.

87. Deming DA, Leystra AA, Nettekoven L, Sievers C, Miller D, Middlebrooks M Clipson L, Albrecht D, Bacher J, Washington MK, Weichert J, Halberg RB: PIK3CA and APC mutations are synergistic in the development of intestinal cancers. Oncogene 2013. doi:10.1038/onc.2013.167.

88. Liu J, Stevens J, Rote CA, Yost HJ, Hu Y, Neufeld KL, White RL, Matsunami N: Siah-1 mediates a novel beta-catenin degradation pathway linking p53 to the adenomatous polyposis coli protein. Mol Cell 2001, 7:927-936.

89. Matsuzawa SI, Reed JC: Siah-1, SIP, and Ebi collaborate in a novel pathway for beta-catenin degradation linked to p53 responses. Mol Cell 2001, 7:915-926.

90. Rother K, Johne C, Spiesbach K, Haugwitz U, Tschöp K, Wasner M, Klein-Hitpass L, Möröy T, Mössner J, Engeland K: Identification of Tcf-4 as a transcriptional target of p53 signalling. Oncogene 2004, 23:3376-3384.

91. Kim NH, Kim HS, Kim N-G, Lee I, Choi H-S, Li X-Y, Kang SE, Cha SY, Ryu JK, Na JM, Park C, Kim K, Lee S, Gumbiner BM, Yook JI, Weiss SJ: p53 and microRNA-34 are suppressors of canonical Wnt signaling. Science signaling 2011, 4:ra71.

92. Reed KR, Meniel VS, Marsh V, Cole A, Sansom OJ, Clarke AR: A limited role for p53 in modulating the immediate phenotype of Apc loss in the intestine. BMC Cancer 2008, 8:162.

93. Neufeld KL, Nix DA, Bogerd H, Kang Y, Beckerle MC, Cullen BR, White RL: Adenomatous polyposis coli protein contains two nuclear export signals and shuttles between the nucleus and cytoplasm. Proc Natl Acad Sci USA 2000, 97:12085-12090

94. Neufeld KL, Zhang F, Cullen BR, White RL: APC-mediated downregulation of beta-catenin activity involves nuclear sequestration and nuclear export. EMBO Rep 2000, 1:519-523.

95. Rosin-Arbesfeld R, Cliffe A, Brabletz T, Bienz M: Nuclear export of the APC tumour suppressor controls beta-catenin function in transcription. EMBO J 2003, 22:1101-1113.

96. Rosin-Arbesfeld R, Townsley F, Bienz M: The APC tumour suppressor has a nuclear export function. Nature 2000, 406:1009-1012.

97. Anderson CB, Neufeld KL, White RL: Subcellular distribution of Wnt pathway proteins in normal and neoplastic colon. Proc Natl Acad Sci USA 2002, 99:8683-8688

98. Zeineldin M, Cunningham J, McGuinness W, Alltizer P, Cowley B, Blanchat B, Xu W, Pinson D, Neufeld KL: A knock-in mouse model reveals roles for nuclear Apc in cell proliferation, Wnt signal inhibition and tumor suppression. Oncogene 2012, 31:2423-2437.

99. Mokry M, Hatzis P, Schuijers J, Lansu N, Ruzius F-P, Clevers H, Cuppen E: Integrated genome-wide analysis of transcription factor occupancy, RNA polymerase II binding and steady-state RNA levels identify differentially regulated functional gene classes. Nucleic Acids Res 2012, 40:148-158.

100. Röhrs S, Kutzner N, Vlad A, Grunwald T, Ziegler S, Müller O: Chronological expression of Wnt target genes Ccnd1, Myc, Cdkn1a, Tfrc, Plf1 and Ramp3. Cell Biol Int 2009, 33:501-508.

101. Yang F, Li X, Sharma M, Sasaki CY, Longo DL, Lim B, Sun Z: Linking beta-catenin to androgen-signaling pathway. J Biol Chem 2002, 277:11336-11344.

102. Song L-N, Coghlan M, Gelmann EP: Antiandrogen effects of mifepristone on coactivator and corepressor interactions with the androgen receptor. Mol Endocrinol 2004, 18:70-85.

103. Pellón-Cárdenas O, Schweitzer J, D'Souza-Schorey C: Endocytic trafficking and Wnt/ß-catenin signaling. Curr Drug Targets 2011, 12:1216-1222.

104. Blitzer JT, Nusse R: A critical role for endocytosis in Wnt signaling. BMC Cell Biol 2006, 7:28.

105. Sun J, Jin T: Both Wnt and mTOR signaling pathways are involved in insulin-stimulated proto-oncogene expression in intestinal cells. Cell Signal 2008, 20:219-229.

106. Sun J, Khalid S, Rozakis-Adcock M, Fantus IG, Jin T: P-21-activated protein kinase- 1 functions as a linker between insulin and Wnt signaling pathways in the intestine. Oncogene 2009, 28:3132-3144.

107. Xie J, Xiang D-B, Wang H, Zhao C, Chen J, Xiong F, Li T-Y, Wang X-L: Inhibition of Tcf-4 induces apoptosis and enhances chemosensitivity of colon cancer cells. PLOS ONE 2012, 7:e45617.

108. De Toni EN, Thieme SE, Herbst A, Behrens A, Stieber P, Jung A, Blum H, Göke $B$, Kolligs FT: OPG is regulated by beta-catenin and mediates 
resistance to TRAIL-induced apoptosis in colon cancer. Clin Cancer Res 2008, 14:4713-4718.

109. Crampton SP, Wu B, Park EJ, Kim J-H, Solomon C, Waterman ML, Hughes CCW: Integration of the beta-catenin-dependent Wnt pathway with integrin signaling through the adaptor molecule Grb2. PLOS ONE 2009, 4:e7841.

110. Yang Y: Wnt signaling in development and disease. Cell Biosci 2012, 2:14.

111. Benetti R, Copetti T, Dell'Orso S, Melloni E, Brancolini C, Monte M, Schneider C: The calpain system is involved in the constitutive regulation of beta-catenin signaling functions. J Biol Chem 2005, 280:22070-22080.

112. Li G, lyengar R: Calpain as an effector of the Gq signaling pathway for inhibition of Wnt/beta -catenin-regulated cell proliferation. Proc Natl Acad Sci USA 2002, 99:13254-13259.

113. Pradeep A, Sharma C, Sathyanarayana P, Albanese C, Fleming JV, Wang TC Wolfe MM, Baker KM, Pestell RG, Rana B: Gastrin-mediated activation of cyclin D1 transcription involves beta-catenin and CREB pathways in gastric cancer cells. Oncogene 2004, 23:3689-3699.

114. Ye P, Hu Q, Liu H, Yan Y: D'ercole AJ: beta-catenin mediates insulin-like growth factor-I actions to promote cyclin D1 mRNA expression, cell proliferation and survival in oligodendroglial cultures. Glia 2010, 58:1031-1041.

115. Hu Q, Lee SY, O'Kusky JR, Ye P: Signaling Through the Type 1 Insulin-Like Growth Factor Receptor (IGF1R) Interacts with Canonical Wnt Signaling to Promote Neural Proliferation in Developing Brain. ASN Neuro 2012, 4:253-265.

116. Tanaka A, Itoh F, Nishiyama K, Takezawa T, Kurihara H, Itoh S, Kato M: Inhibition of endothelial cell activation by bHLH protein E2-2 and its impairment of angiogenesis. Blood 2010, 115:4138-4147.

117. Van der Flier $L G$, Van Gijn ME, Hatzis P, Kujala P, Haegebarth A, Stange DE, Begthel H, van den Born M, Guryev V, Oving I, van Es JH, Barker N, Peters PJ, van de Wetering M, Clevers H: Transcription factor achaete scute-like 2 controls intestinal stem cell fate. Cell 2009, 136:903-912.

118. Hulsen T, de Vlieg J, Alkema W: BioVenn - a web application for the comparison and visualization of biological lists using area-proportional Venn diagrams. BMC Genomics 2008, 9:488.

119. Smoot ME, Ono K, Ruscheinski J, Wang P-L, Ideker T: Cytoscape 2.8: new features for data integration and network visualization. Bioinformatics 2011, 27:431-432.

120. Gao J, Ade AS, Tarcea VG, Weymouth TE, Mirel BR, Jagadish HV, States DJ: Integrating and annotating the interactome using the MiMl plugin for cytoscape. Bioinformatics 2009, 25:137-138.

121. Edgar R, Domrachev M, Lash AE: Gene Expression Omnibus: NCBI gene expression and hybridization array data repository. Nucleic Acids Research 2002, 30:207-210.

doi:10.1186/1471-2164-15-74

Cite this article as: Herbst et al:: Comprehensive analysis of $\beta$-catenin target genes in colorectal carcinoma cell lines with deregulated Wnt/B-catenin signaling. BMC Genomics 2014 15:74.

\section{Submit your next manuscript to BioMed Central and take full advantage of:}

- Convenient online submission

- Thorough peer review

- No space constraints or color figure charges

- Immediate publication on acceptance

- Inclusion in PubMed, CAS, Scopus and Google Scholar

- Research which is freely available for redistribution 